\title{
High quality cassava peel mash supplemented with direct fed microbial as an alternate source of energy supplement: Effects on performance and blood parameters in growing pig
}

*Adesehinwa, A. O. K., ${ }^{1}$ Fatufe, A. A., ${ }^{1}$ Ajayi, E., ${ }^{2}$ Abiola, J. O. , ${ }^{3}$ Adeleye, O. O., Boladuro, B., Afolabi, O. O. and ${ }^{4}$ Amole, T. A.

Institute of Agricultural Research and Training, Obafemi Awolowo University, Ibadan.

${ }^{1}$ Department of Animal Sciences, Obafemi Awolowo University, Ile-Ife.

${ }^{2}$ Department of Veterinary Medicine, University of Ibadan, Ibadan.

${ }^{3}$ Department of Animal Production and Health,

Federal University of Agriculture, Abeokuta.

${ }^{4}$ International Livestock Research Institute (ILRI), IITA Premises, Ibadan.

Abstract

*Corresponding Email: aokadesehinwa@yahoo.com

The feeding trial was carried out to determine the effect offeeding high quality cassava peel mash (HQCP) with or without multi-strain direct fed microbials (DFM) as replacement for maize in the diet of growing pigs on growth, cost benefit, haematology and serum biochemical indices. A total of 90 growing pigs with an initial weight of $25.36 \pm 0.87 \mathrm{~kg}$ were randomly assigned to five dietary treatments in a $2 \times 2+1$ factorial arrangement in a completely randomised design. The factors were 2 levels of $H Q C P(7.5 \%$ and $15 \%)$, two DFM inclusions and a control diet with neither HQCP nor DFM. Pigs on T1 were given corn (40\%) based diet without HQCP, T2 had $18.75 \%$ of Maize (7.5kg) replaced by HQCP and T3 had $37.5 \%$ of total Maize (15kg) replaced by HQCP. The pigs in T4 were given same diet as in T2 with addition of multi-strain DFM and animals on T5 were given the same diet with those on T3 with addition of multi-strain DFM microbial. Each treatment group had three replicates with six animals per replicate. No significant $(P>0.05)$ difference was observed in the performance characteristics of the growing pigs among the diets. The body weight gain ranged between 10.97 and $13.56 \mathrm{Kg}$ in T5 and T3, respectively. The least feed conversion ratio of 3.98 was observed in T3 while the highest feed conversion ratio (4.77) was observed in T5. All the haematological and serum biochemical indices examined were not significantly $(P>0.05)$ different among the treatments. There was no significant $(P>0.05)$ effect of $H Q C P$, $D F M$ or their interaction on all the haematological parameters analysed. There was significant effect of HQCP and DFM interaction on the serum cholesterol ( $p=0.0062)$, high density lipoprotein $(p=0.05)$ and low density lipoprotein $(p=0.0018)$. It can be concluded from this study that growing pigs can utilize HQCP up to $15 \%$ in their diet without any adverse effect.

Keywords: Direct fed microbials, High quality cassava peels, Maize, Multi-strain direct fed microbials, Pigs.

\section{Introduction}

The increase in the demand for cassava root is increasing daily. The increased utilisation of cassava roots as food for human consumption and its use for the production of flour, starch and ethanol for industrial purposes may affect its availability for use as livestock feed ingredient as a result of increased cost per unit. Cassava peel which is considered a by product in the processing of cassava for industrial and domestic use has been identified as potential source of energy in the diet of livestock. Being a byproduct from processing of cassava root, it is cheaper than cassava root (Adesehinwa $e t$ $a l ., 2016)$ and most conventional energy 


\section{High quality cassava peel mash supplemented with direct fed microbial}

source such as maize, millet and guinea corn used in livestock feed production. However, fresh cassava peel contains large amount of cyanogenic glycosides and phytate (up to 1\% DM) (Tewe, 1992; Salami et al, 2003; Oboh, 2006) and rotten easily because of its high moisture content. The International Livestock Research Institute (ILRI, 2015), developed an innovative method of processing cassava peels by grating, pressing, sieving and drying to produce High Quality Cassava Peel (HQCP) mash (Okike et al., 2015) thereby eliminating the anti-nutritional factors that limit the use of cassava peel as livestock feed ingredients. Adesehinwa et al. (2016) reported that HQCP can be included up to $30 \%$ in the diet of growing pigs. The addition of feed additives to the diet of pigs may also enhance the utilisation of HQCP as an alternate energy source in the diet of growing pigs. The relevance of use of feed additives in animal production for improved feed utilisation, health and productivity cannot be over-emphasized. While the use of some additives are encouraged because of their enormous beneficial effects, the use of antibiotics growth promoters as an additive in the diets of livestock is being discouraged because of the challenge of anti-microbial resistance that pathogens develop and possible transference of this from animal to human microbiota as a result of routine use of antibiotics. This resulted in the emergence of organic acids and their salts, phytogenic additives, prebiotics and direct fed microbials (probiotics) as alternatives to antibiotic growth promoters. Direct fed microbials (DFM) are live (viable) naturally occurring micro-organisms fed to animals to improve the gut microbial environment for the benefit of the host and this includes bacteria, fungi and yeast. DFMs are beneficial to the host by maintaining normal intestinal microflora by competitive exclusion and antagonism (Kabil et al., 2005; Flint and Garner, 2009; Kabir, 2009; Kizerwetter-Swidaand Binek, 2009). They alter metabolism by increasing digestive enzyme activity and decreasing bacterial enzyme activity and ammonia; improve feed intake and digestion and also stimulating the immune system (Kabil et al., 2005; Kabir, 2009; Kizerwetter-Swida and Binek, 2009; Chaucheyras-Durand and Durand, 2010). For example, Lactobacillus acidophilus as reported by Flint and Garner (2009) could control/prevent invasion of the epithelial wall of the gastrointestinal track by Escherichia coli, Yersinia pseudotuberculosis and Salmonella enterica ssp. enteric (Bernet et al., 1994; Tindal et al., 2005; Flint and Garner, 2009). The Bacillus ssp. and Saccharomyces cerevisiae have been reported to perform immunestimulatory functions (Flint and Garner, 2009). However, using multi-strain or multi-species probiotics have been discovered to be more effective than monostrain or single-species probiotics (Timmerman et al., 2004). The health status of an animal is reflective in the haematological and serum biochemical indices of such animal. Haematological and serum biochemical indices are also good indicators of the physiological status of an animal (Khan and Zafar, 2005). As part of the process of digestion in the gastrointestinal tract, nutrients are absorbed into the blood stream through different mechanism. Isaac et al. (2013) reported that animals with good blood composition are likely to show good performance. Thus, this study aimed at investigating the effect of supplementing high quality cassava peel mash with direct fed microbials as an alternate energy source in the diet of growing pigs on the performance characteristics, cost benefit, haematological and serum biochemical indices. 


\section{Adesehinwa, Fatufe, Ajayi, Abiola, Adeleye, Boladuro, Afolabi and Amole}

\section{Materials and methods \\ Experimental location, animals, design and diet}

This experiment was carried out at $\mathrm{AK}$ farms, Eleyele, Ibadan, Oyo State, Nigeria. A total of ninety growing pigs which are crosses of Large White and Landrace with an average weight of $25.36 \pm 0.87 \mathrm{~kg}( \pm \mathrm{SE})$ were used for this study. The animals were randomly allotted to five dietary treatments in a $2 \times 2+1$ factorial arrangement in a completely randomized design. Each treatment was replicated three times with six pigs per replicate. The factors in the factorial arrangement were two (2) levels of HQCP (7.5 and $15 \%$ of the diet), two (2) direct fed microbial (DFM) inclusions and a (1) control diet which had neither HQCP nor DFM inclusion. The diets were formulated to meet the nutrient requirement for growing pigs according to National Research Council (1998) recommendation for growing pigs. The diets across the treatments were formulated to be isonitrogenous and isocaloric. The gross composition of the experimental diet is as shown in Table 1. The basal diet composed of maize, groundnut cake and Palm kernel cake. High Quality Cassava peel replaced maize in basal diet in treatment 2 to treatment 5. The Pigs placed on T1 were given maize (40\%) based diet with neither HQCP nor DFM; those in T2 had $7.5 \mathrm{~kg}$ HQCP replacing $18.75 \%$ of the maize portion of the diet while T3 were fed $15 \mathrm{~kg}$ HCQP replacing $37.5 \%$ of the maize portion in the diet. The pigs on T4 were given the same diet as those in T2 except with the addition of multi-strain DFM, while T5 were fed same diet with those on T3 with the addition of the multi-strain DFM. The multi-strain DFM contained 11x $10^{5} \mathrm{CFU} / \mathrm{g}$ Saccharomyces, $1 \times 10^{8} \mathrm{CFU} / \mathrm{g}$ Lactobacillus sp, $4 \times 10^{12} \mathrm{CFU} / \mathrm{g}$ Bacillus sp and $99.9 \%$ water and it was added to the feed at $1.6 \mathrm{ml} / \mathrm{kg}$ of feed. The pigs were fed ad-libitum throughout the feeding trial which spanned 56 days.

The initial weight of the pigs was determine at the beginning of the study and they were weighed weekly thereafter till the end of the study using a measuring scale. The body weight gain was estimated as the difference between the finial and the initial weight. The feed intake of the pigs was determined daily as the weight difference between the feed given and the leftover. The feed conversion ratio was estimated as the ratio of feed given to weight gain.

At the end of the feeding trial, blood was sampled through the jugular vein of the animals using hypodermic needle and syringe. Blood sampled for haematological and serum biochemical analyses were emptied into sample bottles with anticoagulant and without anti-coagulant respectively.

The proximate composition of the diets was determined according to the method of AOAC (2005). Data obtained were subjected to analysis of variance (ANOVA) appropriate for factorial design using the general linear model procedures of SAS. Statistical significance was assessed at $\mathrm{P}<$ 0.05 .

\section{Results and discussion}

The determined proximate composition of the experimental diets as highlighted in Table 2 showed that the diets are isonitrogenous and isocaloric. The crude protein ranged between 17.53 and 18.84 in $\mathrm{T} 1$ and T5 respectively. This is similar to what was recommended by Irekhore et al. (2015) as adequate to support the performance of growing pigs. The highest crude fibre content of $6.29 \%$ was determined in diet T3 with 15\% HQCP without DFM while the least (5.84) was recorded in $\mathrm{T} 1$. The determined fiber fraction of the experimental diet is as shown 


\section{High quality cassava peel mash supplemented with direct fed microbial}

Table1: Ingredient composition of diets having graded level of high quality cassava peel mash

\begin{tabular}{|c|c|c|c|c|c|}
\hline Ingredients \% & $\mathrm{T} 1$ & $\mathrm{~T} 2$ & $\mathrm{~T} 3$ & $\mathrm{~T} 4$ & T5 \\
\hline Maize & 40 & 32.5 & 25 & 32.5 & 25 \\
\hline HQCP & 0 & 7.5 & 15 & 7.5 & 15 \\
\hline Wheat bran & 10.5 & 9.5 & 8.5 & 9.5 & 8.5 \\
\hline Palm oil & 1.5 & 2.5 & 3.5 & 2.5 & 3.5 \\
\hline Other & 48 & 48 & 48 & 48 & 48 \\
\hline Total & 100 & 100 & 100 & 100 & 100 \\
\hline \multicolumn{6}{|l|}{ Calculated analysis } \\
\hline Crude fibre (\%) & 5.06 & 5.48 & 5.90 & 5.48 & 5.90 \\
\hline Crude protein (\%) & 20.55 & 20.20 & 19.86 & 20.20 & 19.86 \\
\hline Metabolizable energy $(\mathrm{kcal} / \mathrm{kg})$ & 2754.85 & 2782.47 & 2810.10 & 2782.47 & 2810.10 \\
\hline Calcium & 1.67 & 1.68 & 1.69 & 1.68 & 1.69 \\
\hline Phosphorus & 0.80 & 0.79 & 0.79 & 0.79 & 0.79 \\
\hline Lysine & 1.09 & 1.07 & 1.04 & 1.07 & 1.04 \\
\hline Methionine & 0.38 & 0.36 & 0.35 & 0.36 & 0.35 \\
\hline
\end{tabular}

in Table 3. The Neutral detergent fibre was seen to be 5.84, 6.08, 6.14, 6.24 and $6.29 \%$ in $\mathrm{T} 1, \mathrm{~T} 4, \mathrm{~T} 2, \mathrm{~T} 5$ and $\mathrm{T} 3$, respectively. This similar trend was observed in other fibre fractions except for Hemicellulose. The NDF in T4 (47.54\%) and T5 (48.40\%) was observed to be numerically lower to what was recorded in $\mathrm{T} 2(47.61 \%)$ and $\mathrm{T} 3(48.67$
$\%)$, respectively despite having the same level of all ingredients except for the presence of DFM in T4 and T5 was observed to have lower NDF. Similar trend was observed in the other fibre fractions including the Hemicellulose. This could be attributed to the addition of DFM to the diets.

Table 2: Proximate composition of experimental diets

\begin{tabular}{llllll}
\hline Parameters $(\%)$ & T1 & T2 & T3 & T4 & T5 \\
\hline Dry matter & 93.25 & 92.35 & 91.35 & 91.90 & 90.95 \\
Crude Protein & 17.53 & 17.74 & 18.64 & 17.83 & 18.84 \\
Crude Fibre & 5.84 & 6.14 & 6.29 & 6.08 & 6.24 \\
Crude fat & 3.6 & 3.64 & 3.7 & 3.68 & 3.74 \\
Ash & 6.32 & 6.41 & 6.51 & 6.45 & 6.60 \\
NFE & 57.395 & 56.845 & 55.735 & 56.775 & 55.50 \\
Gross energy $(\mathrm{kcal} / \mathrm{kg})$ & 4.010 & 4.042 & 4.025 & 4.037 & 4.033 \\
\hline
\end{tabular}

NFE - Nitrogen Free Extract

Table 3: Fiber fraction of experimental diets

\begin{tabular}{llllll}
\hline Parameters (\%) & T1 & T2 & T3 & T4 & T5 \\
\hline Crude Fibre & 5.84 & 6.14 & 6.29 & 6.08 & 6.24 \\
NDF & 45.14 & 47.61 & 48.67 & 47.54 & 48.40 \\
ADF & 20.06 & 23.58 & 25.15 & 23.51 & 25.10 \\
ADL & 6.60 & 6.67 & 6.90 & 6.64 & 6.78 \\
Hemicellulose & 25.08 & 24.04 & 23.52 & 24.03 & 23.30 \\
Cellulose & 13.46 & 16.91 & 18.25 & 16.86 & 18.32 \\
\hline
\end{tabular}

NDF- Neutral Detergent Fiber, ADF - Acid Detergent Fiber, ADL- Acid Detergent Lignin, \% - percent 
Direct fed microbials (DFM) are fed to livestock to improve the health and feed utilization of the animal. The growth of growing pigs fed high quality cassava peel (HQCP) supplemented with direct fed microbial (DFM) is shown in Table 4. The highest final weight of $40.25 \mathrm{~kg}$ was recorded in diet T2 fed $15 \mathrm{~kg} \mathrm{HQCP}$ as replacement for maize portion of the diet. This is however not significantly $(\mathrm{P}>0.05)$ different from what was recorded in other treatments. The lowest final weight (36.77 $\mathrm{kg}$ ) was recorded in diet $\mathrm{T} 4$. The supplementation of the DFM $\left(1 \times 10^{8} \mathrm{CFU} / \mathrm{g}\right.$ Lactobacillus sp, $4 \times 10^{12} \mathrm{CFU} / \mathrm{g}$ Bacillus sp and $11 \times 10^{5} \mathrm{CFU} / \mathrm{g}$ Saccharomyces cerevisiae) was not seen to significantly $(\mathrm{P}>0.05)$ influence the body weight gain and FCR of the growing pigs among the treatments in this study. This result corroborates the work of Chen et al. (2005) and Giang et al. (2011) where feeding of combination of Bacillus subtillis,
Saccharomyces ssp and a lactic acid bacteria (LAB) was not found to significantly $(\mathrm{P}>0.05)$ influence growth response of growing pigs. According to Stavric and Kornegay (1995), probiotics are more effective in animals during microflora development or when microflora stability has been impaired. The feed intake among the treatments was not significantly influenced by the inclusion of HQCP and DFM in the diets of the pigs. The least FCR of 3.98 was recorded in T3 while the highest (4.77) was recorded in diet T5. The effect of HQCP, DFM and their interactions on weight gain, feed intake and feed conversion ratio were shown in Table 5. The single effect of the DFM and HQCP level were not significant $(\mathrm{P}>0.05)$ for all the growth parameters, likewise, their interactions were also not significant for all the growth performance parameters taken. This is an indication that growing pig can effectively utilize the diets without any adverse effect.

Table 4 : Growth response of growing pigs fed high quality cassava peel supplemented with direct fed

\begin{tabular}{|c|c|c|c|c|c|c|c|c|c|}
\hline \multicolumn{2}{|l|}{$\frac{\text { marameters }}{\text { Pand }}$} & \multicolumn{2}{|l|}{$\mathrm{T} 2$} & $\mathrm{~T} 3$ & \multicolumn{2}{|c|}{$\mathrm{T} 4$} & $\mathrm{~T} 5$ & P Value & SEM \\
\hline Initial weight $(\mathrm{Kg})$ & 25.95 & \multicolumn{2}{|l|}{26.97} & 23.81 & \multicolumn{2}{|c|}{23.77} & 26.28 & 0.70 & 0.87 \\
\hline Final weight $(\mathrm{Kg})$ & 38.92 & \multicolumn{2}{|l|}{40.25} & 37.36 & \multicolumn{2}{|c|}{36.77} & 37.25 & 0.93 & 1.31 \\
\hline BWG (Kg) & 12.97 & \multicolumn{2}{|l|}{13.28} & 13.56 & \multicolumn{2}{|c|}{13.00} & 10.97 & 0.49 & 0.49 \\
\hline DWG $(\mathrm{g})$ & 308.90 & \multicolumn{2}{|l|}{316.22} & 322.75 & \multicolumn{2}{|c|}{309.52} & 261.24 & 0.49 & 11.76 \\
\hline TFI $(\mathrm{g})$ & 53128 & \multicolumn{2}{|l|}{55468} & 49493 & \multicolumn{2}{|c|}{51628} & 50058 & 0.71 & 1430.24 \\
\hline ADFI (g) & 1265.00 & \multicolumn{2}{|c|}{1320.70} & 1178.40 & \multicolumn{2}{|c|}{1229.20} & 1191.80 & 0.71 & 34.05 \\
\hline FCR & 4.50 & 4.40 & & 3.98 & \multicolumn{2}{|c|}{4.35} & 4.77 & 0.51 & 0.14 \\
\hline \multicolumn{10}{|c|}{$\begin{array}{l}\text { BWG - Body weight gain, DWG - Daily weight gain, TFI - Total feed intake, ADFI - Average daily feed intake, FCR - Feed conversion ratio, } \\
\text { SEM - Standard error of mean }\end{array}$} \\
\hline \multicolumn{10}{|c|}{$\begin{array}{l}\text { Table } 5 \text { : Interaction between high quality cassava peel level and direct fed microbial on performance of } \\
\text { grower pigs fed experimental diets }\end{array}$} \\
\hline & & & & & & & & $\mathrm{P} \mathrm{Va}$ & \\
\hline Parameters & $\mathrm{T} 2$ & $\mathrm{~T} 3$ & $\mathrm{~T} 4$ & $\mathrm{~T} 5$ & & SEM & DFM & $\begin{array}{l}\text { HQCP } \\
\text { LEVEL }\end{array}$ & $\begin{array}{l}\text { DFM* HQCP } \\
\text { LEVEL }\end{array}$ \\
\hline Initial weight $(\mathrm{Kg})$ & 26.97 & 23.81 & 23.77 & 26. & & 1.056 & 0.86 & 0.88 & 0.19 \\
\hline Final weight (Kg) & 40.25 & 37.36 & 36.77 & 37. & & 1.56 & 0.57 & 0.71 & 0.60 \\
\hline BWG (Kg) & 13.28 & 13.56 & 13.00 & 10. & & 0.56 & 0.20 & 0.44 & 0.31 \\
\hline DWG $(\mathrm{g})$ & 316.22 & 322.75 & 309.52 & 261 & & 13.32 & 0.20 & 0.44 & 0.30 \\
\hline TFI (g) & 55468 & 49493 & 51628 & 500 & & 1711 & 0.64 & 0.28 & 0.53 \\
\hline ADFI (g) & 1320.70 & 1178.40 & 1229.20 & & .80 & 40.74 & 0.64 & 0.28 & 0.53 \\
\hline FCR & 4.40 & 3.98 & 4.35 & 4.7 & & 0.16 & 0.24 & 1.00 & 0.18 \\
\hline
\end{tabular}




\section{High quality cassava peel mash supplemented with direct fed microbial}

The cost benefit analysis of feeding HQCP and DFM in the diet of growing pigs is shown in Table 6. Feed constitute 60-80\% of the variable cost of production in a livestock enterprise. Achieving a comparable good performance by feeding at reduced cost will be beneficial in production. The feed cost among the treatments differs significantly $(\mathrm{P}<0.05)$ from one another. The significantly $(\mathrm{P}<0.05)$ lowest feed cost of $\mathrm{N} 131.75 / \mathrm{kg}$ of feed was recorded in diet $\mathrm{T} 3$ fed the highest level of HQCP without DFM while the significantly highest feed cost of $\$ 137.76 / \mathrm{kg}$ was recorded in $\mathrm{T} 4$. The addition of DFM to diet as in T4 and T5 increased the cost of the feed when compared with $\mathrm{T} 2$ and $\mathrm{T} 3$ respectively that has the same level of HQCP but without DFM. The feed cost per weight gain showed no significant difference among the treatments and ranged between $\$ 524.31$ and $\$ 643.79$ in treatment $\mathrm{T} 3$ and $\mathrm{T} 5$, respectively.

\begin{tabular}{|c|c|c|c|c|c|c|}
\hline Parameters & $\mathrm{T} 1$ & $\mathrm{~T} 2$ & T3 & $\mathrm{T} 4$ & $\mathrm{~T} 5$ & \pm SEM \\
\hline Cost of feed $(\mathrm{N} / \mathrm{Kg})$ & $137.37^{\mathrm{b}}$ & $134.56^{\mathrm{d}}$ & $131.75^{\mathrm{e}}$ & $137.76^{\mathrm{a}}$ & $134.95^{\mathrm{c}}$ & 0.23 \\
\hline Total Feed Intake (Kg) & 53.13 & 55.47 & 49.49 & 51.63 & 50.06 & 1.43 \\
\hline Average Daily Feed Intake (Kg) & 1.27 & 1.32 & 1.18 & 1.23 & 1.19 & 0.03 \\
\hline Total cost of feeding (A) & 7298.1 & 7463.6 & 6520.6 & 7112.1 & 6755.2 & 194.49 \\
\hline Average cost of feed per day (N) & 173.77 & 177.70 & 155.25 & 169.34 & 160.84 & 4.63 \\
\hline Feed Gain Ratio & 4.50 & 4.40 & 3.98 & 4.35 & 4.77 & 0.14 \\
\hline Feed Cost/kg Weight Gain ( $/ \mathrm{Kg})$ & 618.53 & 592.48 & 524.31 & 598.85 & 643.79 & 19.35 \\
\hline
\end{tabular}

SEM - Standard error of mean

The effect of feeding HQCP supplemented with DFM in the diets of growing pigs on the haematological parameters is shown in Table 7. There was no significant $(\mathrm{P}>0.05)$ difference observed in all the parameters examined. The highest concentration of lymphocyte $(54.00 \%)$ was recorded on $\mathrm{T} 1$ where the diet contained no inclusion of HQCP and DFM while the lowest concentration of the lymphocyte was observed in T3. The values obtained for haematological parameters in this study falls within the physiological normal range of a healthy pig (Merck Manual, 2012). The level of RBC and WBC recorded from this study indicates that no pathological effect was induced and thus, the health of the animals was not comprised. This support the report of Chen et al. (2005) and Ojebiyi et al. (2015) that the addition of direct fed microbials (DFM) to diet of livestock does not illicit pathogenic effect on the host. The interactive effect of feeding HQCP and DFM to growing pigs on haematological parameters is as displayed in Table 8. No significant $(\mathrm{P}>0.05)$ effect of HQCP, DFM or their interaction was observed on the PCV, haemoglobin concentration, erythrocyte, leukocytes, lymphocytes, neutrophils, monocytes, eosinophils and platelets.

Table 7: Effect of direct fed microbials and high quality cassava peel on the haematology of growing pigs

\begin{tabular}{llllllll}
\hline Parameters & T1 & T2 & T3 & T4 & T5 & P Value & SEM \\
\hline PCV $(\%)$ & 34.500 & 34.500 & 31.000 & 32.750 & 35.250 & 0.7500 & 1.047 \\
H.b & 11.500 & 11.498 & 10.335 & 10.913 & 11.750 & 0.7504 & 0.35 \\
RBC $\left(10^{6}\right)$ & 6.120 & 6.700 & 6.453 & 6.053 & 7.060 & 0.8442 & 0.29579 \\
WBC $\left(10^{3}\right)$ & 8638 & 8950 & 7175 & 7613 & 9838 & 0.7463 & 645.450 \\
Lymp $(\%)$ & 54.00 & 51.75 & 47.25 & 49.75 & 48.50 & 0.1825 & 0.965 \\
Neut $(\%)$ & 39.25 & 41.50 & 45.50 & 44.25 & 44.75 & 0.2030 & 0.958 \\
Mono (\%) & 3.50 & 2.75 & 2.75 & 2.25 & 3.00 & 0.4910 & 0.225 \\
Eos $(\%)$ & 3.25 & 4.00 & 4.75 & 5.00 & 3.75 & 0.4550 & 0.327 \\
Platelet & 148250 & 199750 & 147750 & 125000 & 171500 & 0.5307 & 13711.21 \\
\hline Note: SEM = Standard error of mean, DFM = Direct fed microbial, PCV = Packed cell volume, $\mathbf{H b}=$ Haemoglobin, RBC = Red blood cells, WBC = White \\
blood cells, Lymp = Lymphocyte, Neut - Neutrophils, Mono = Monocytes, Eos = Eosinophils.
\end{tabular}


Adesehinwa, Fatufe, Ajayi, Abiola, Adeleye, Boladuro, Afolabi and Amole

Table 8: Interactive effect of directfed microbials and high quality cassava peelon haematology of growing pig

\begin{tabular}{|c|c|c|c|c|c|c|c|c|}
\hline \multirow[b]{2}{*}{ Parameters } & \multirow[b]{2}{*}{$\mathrm{T} 2$} & \multirow[b]{2}{*}{$\mathrm{T} 3$} & \multirow[b]{2}{*}{$\mathrm{T} 4$} & \multirow[b]{2}{*}{ T5 } & \multirow[b]{2}{*}{ SEM } & \multicolumn{3}{|c|}{ P Value } \\
\hline & & & & & & DFM & $\begin{array}{l}\text { HQCP } \\
\text { LEVEL }\end{array}$ & $\begin{array}{l}\text { DFM* HQCP } \\
\text { LEVEL }\end{array}$ \\
\hline PCV (\%) & 34.500 & 31.000 & 32.750 & 35.250 & 1.224 & 0.6352 & 0.8489 & 0.2654 \\
\hline H.b (g/dL) & 11.498 & 10.335 & 10.913 & 11.750 & 0.41 & 0.6365 & 0.8526 & 0.2653 \\
\hline $\operatorname{RBC}\left(10^{6}\right)$ & 6.700 & 6.453 & 6.053 & 7.060 & 0.35 & 0.9795 & 0.6272 & 0.4265 \\
\hline $\operatorname{WBC}\left(10^{3}\right)$ & 8950 & 7175 & 7613 & 9838 & 690.07 & 0.6483 & 0.8766 & 0.1835 \\
\hline Lymp (\%) & 51.75 & 47.25 & 49.75 & 48.50 & 1.06 & 0.8655 & 0.2092 & 0.4676 \\
\hline Neut $(\%)$ & 41.50 & 45.50 & 44.25 & 44.75 & 1.00 & 0.6376 & 0.2982 & 0.4142 \\
\hline Mono (\%) & 2.750 & 2.7500 & 2.2500 & 3.00 & 0.26 & 1.0000 & 0.6573 & 0.3809 \\
\hline $\operatorname{Eos}(\%)$ & 4.00 & 4.75 & 5.00 & 3.75 & 0.33 & 1.0000 & 0.7153 & 0.1610 \\
\hline Platelet & 199750 & 147750 & 125000 & 171500 & 16076.12 & 0.4434 & 0.9333 & 0.1518 \\
\hline
\end{tabular}

Note: SEM = Standard error of mean, PCV = Packed cell volume, Hb= Haemoglobin, RBC $=$ Red blood cells, WBC = White blood cells, Lymp = Lymphocite, Neut - Neutrophils, Mono = Monocytes, Eos = Eosinophils, DFM - Effect of direct fed microbial, HQCP LEVEL - Effect of high quality cassava peel level, DFM* HQCP LEVEL-Interaction between level of high quality cassava peel and direct fed microbial.

The serum biochemical analysis helps in providing information about state of tissues, organs and metabolic state of the body. The serum biochemistry of growing pigs fed HQCP and DFM in the diet is as presented in Table 9. The serum biochemical indices observed in this study did not differ significantly $(\mathrm{P}>0.05)$ among the treatments. This result is similar to the report of Chen et al. (2005) who stated that determined haematology and serum chemistry parameters including Albumin, total protein, RBC, WBC and lymphocyte were not affected by the addition of Lactobacillus acidophilus 1.0×107 CFU/g, Saccharomyces cerevisae $4.3 \times 106 \mathrm{CFU} / \mathrm{g}$ and Bacillus subtilis $2.0 \times 106 \mathrm{CFU} / \mathrm{g}$ to diet of growing pigs. The lower cholesterol level in observed in diet T5 with probiotics supplementation could be attributed to probiotics effect and its ability to bind cholesterol in the small intestines (Ojebiyi et al., 2015). The serum biochemical value reported in this study falls within the normal physiological range of a healthy animal (Merck Manual, 2012). In another study reported by Adesehinwa et al. (2016), replacing maize with HQCP up30\% in the diet of growing pigs did not influence the haematological and serum biochemical properties of the pigs negatively.

According to Yang et al. (2015), Lactic acid bacteria (LAB) can inhibit pathogenic bacteria by competing for nutrients in the gut or at binding sites in the intestinal epithelium (Malago and Koninkx, 2011) and thus prevent them from eliciting pathogenic effect on the host (Havenaar et al., 1992). As indicated in Table 10, there was significant effect of HQCP and DFM interaction on the serum cholesterol $(\mathrm{p}=0.0062)$, high density $(\mathrm{p}=0.05)$ and low density lipoprotein cholesterol $(\mathrm{p}=0.0018)$.

Table 9: Serum biochemistry of growing pigs fed high quality cassava peel and direct fed microbials

\begin{tabular}{llllllll}
\hline Parameters & T1 & T2 & T3 & T4 & T5 & P Value & SEM \\
\hline Chol (mg/dl) & 142.50 & 129.17 & 176.25 & 170.42 & 119.58 & 0.0805 & 8.03 \\
UR (mg/dl) & 22.23 & 18.99 & 19.29 & 22.01 & 21.66 & 0.1949 & 0.57 \\
CRT (mg) & 1.50 & 1.58 & 1.50 & 1.70 & 1.25 & 0.4252 & 0.07 \\
HDL (mg/dl) & 59.45 & 49.72 & 63.89 & 59.45 & 52.78 & 0.5182 & 2.73 \\
LDL (mg/dl) & 19.945 & 21.910 & 17.020 & 17.705 & 18.62 & 0.0672 & 0.61 \\
Thio (mg/ml) & 17.04 & 16.73 & 18.68 & 17.83 & 16.78 & 0.5413 & 0.40 \\
AST ( I.U/l) & 25.92 & 16.55 & 23.22 & 30.98 & 24.41 & 0.3980 & 2.25 \\
ALP (I.U/l) & 46.25 & 50.72 & 48.22 & 48.39 & 51.52 & 0.9251 & 1.85 \\
\hline
\end{tabular}

Note: SEM - Standard error of mean, Chol- Cholesterol, UR - Urea, CRT - Creatinine, Thio- Thiocyanate, AST - Aspertate amino transferase,

ALP - Alkaline phosphatase, HDL - High density lipoprotein LDL - Low density lipoprotein 
High quality cassava peel mash supplemented with direct fed microbial

Table 10: Interactive effect of direct fed microbials on serum parameters of growing pigs fed experimental diets

\begin{tabular}{|c|c|c|c|c|c|c|c|c|}
\hline \multirow[b]{2}{*}{ Parameters } & \multirow[b]{2}{*}{$\mathrm{T} 2$} & \multirow[b]{2}{*}{$\mathrm{T} 3$} & \multirow[b]{2}{*}{$\mathrm{T} 4$} & \multirow[b]{2}{*}{ T5 } & \multirow[b]{2}{*}{ SEM } & \multicolumn{3}{|c|}{$\mathrm{P}$ Value } \\
\hline & & & & & & DFM & $\begin{array}{l}\text { HQCP } \\
\text { LEVEL }\end{array}$ & $\begin{array}{l}\text { DFM* HQCP } \\
\text { LEVEL }\end{array}$ \\
\hline Chol (mg/dl) & 129.17 & 176.25 & 170.42 & 119.58 & 129.17 & 0.6118 & 0.9012 & 0.0062 \\
\hline UR (mg/dl) & 18.99 & 19.29 & 22.01 & 21.66 & 18.99 & 0.0449 & 0.9846 & 0.7941 \\
\hline CRT (mg) & 1.58 & 1.50 & 1.70 & 1.25 & 1.58 & 0.7126 & 0.1391 & 0.2799 \\
\hline HDL (mg/dl) & 49.72 & 63.89 & 59.45 & 52.78 & 49.72 & 0.8890 & 0.4573 & 0.0542 \\
\hline $\operatorname{LDL}(\mathrm{mg} / \mathrm{dl})$ & 21.910 & 17.020 & 17.705 & 18.62 & 21.910 & 0.0971 & 0.0178 & 0.0018 \\
\hline Thio (mg/ml) & 16.73 & 18.68 & 17.83 & 16.78 & 16.73 & 0.6420 & 0.5968 & 0.0941 \\
\hline AST ( I.U/l ) & 16.55 & 23.22 & 30.98 & 24.41 & 16.55 & 0.1636 & 0.9924 & 0.2320 \\
\hline $\operatorname{ALP}(\mathrm{I} . \mathrm{U} / \mathrm{l})$ & 50.72 & 48.22 & 48.39 & 51.52 & 50.72 & 0.9185 & 0.9476 & 0.5587 \\
\hline
\end{tabular}

Note: SEM - Standard error of mean, Chol - Cholesterol, UR - Urea, CRT - Creatinine, HDL - High density lipoprotein, LDL - Low density lipoprotein, Thio Thiocyanate, AST - Aspertate amino transferase, ALP-Alkaline phosphatase, DFM - Effect of direct fed microbial, HQCP LEVEL- Effect of high quality cassava peel level, DFM* HQCP LEVEL-Interaction between level of high quality cassava peel and direct fed microbial.

\section{Conclusion}

The addition of multi-strain direct fed microbials to high quality cassava peel in the diet of growing pigs was not seen to enhance the performance of the animal. It can be concluded from this study that high quality cassava peel can be used up to $15 \%$ inclusion in the diet as replacement for $37.5 \%$ maize in the diet of growing pigs without direct fed microbials.

\section{References}

Adesehinwa, A. O. K., Samireddypalle, A., Fatufe, A. A., Ajayi, E., Boladuro, B. and Okike, I. 2016. High quality cassava peel fine mash as energy source for growing pigs: effect on growth performance, cost of production and blood parameters. Livestock Research for Rural Development.28(207). http:// www.lrrd.org//rrd28/11/ades2820 7.html

AOAC, 2004. Official methods of analysis. Association of official analytical chemists, 18th edition, Washington D. C., USA. Pp 275-293

Bernet, M. F., Brassart, D. Neeser, J. R. and Servin A. L. 1994. Lactobacillus acidophilus LA 1 binds to cultured human intestinal cell lines and inhibits cell attachment and cell invasion by enterovirulent bacteria. Gut 35: 483-489.

Chaucheyras-Durand, F. and Durand, H. 2010. Probiotics in animal nutrition and health. Beneficial Microbes 1(1): 3-9.

Chen, Y. J., Son, K. S., Min, B. J., Cho, J. H., Kwon, O. S. and Kim, I. H. 2005. Effects of dietary probiotic on growth performance, nutrients digestibility, blood characteristics and fecal noxious gas content in growing pigs. Asian-Australian Journal of Animal Science 18: 1464-1468.

Flint, J. F. and Garner, M. R. 2009. Feeding beneficial bacteria: A natural solution for increasing efficiency and decreasing pathogens in animal agriculture. Journal of Applied Poultry Research 18:367-378.

Giang, H. H., Viet, T. Q., Ogle, B. and Lindberg, J. E. 2011. Effects of supplementation of probiotics on the performance: nutrient digestibility and fecal microflora in growing-finishing pigs. AsianAustralian Journal of Animal Science 24: 655-661.

Havenaar, R., Ten Brink, B., HuisIn'T Veld, J. H. J. 1992. Selection of 
strains for probiotic use. In Probiotic, 1st ed.; Fuller, R., Ed.; Chapman \& Hall: London, UK. Pp. 209-224.

Irekhore, O. T., Adeyemi, O. M., Idowu, O. M. O., Akinola, O. S. and Bello, K. O. 2015. Growth Performance, Haematological Indices and Cost Benefits of Growing Pigs Fed Cassava Peel Meal Diets Supplemented With Allzyme ${ }^{\circledR}$ SSF .International Journal of Applied Agricultural and Apicultural Research 11 (1\&2): 51-59.

Khan, T. A. and Zafar, F. 2005. Haematological study in response to varying doses of estrogen in broiler chicken. International Journal of Poultry Science 4(10): 748-751.

Kizerwetter-Swida, M. and Binek, M. 2009. Protective effect of potentially probiotic Lactobacillus strain on infection with pathogenic bacteria in chickens. Polish Journal of Veterinary Science 12: 15-20.

Malago, J. J. and Koninkx, J. F. 2011. Probiotic-pathogen interactions and enteric cytoprotection. Probiotic bacteria and enteric infection 6: 289-311.

Oboh, G. 2006. Nutrient enrichment of cassava peels using mixed culture of Saccharomyces cerevisae and Lactobacillus spp in solid media fermentation. Electronic Journal of Biotechnology 9(1): 4649.

Okike, I., Samireddypalle, A., Kaptoge, L., Fauquet, C., Atehnkeng, J., Bandyopadhyay. R., Kulakow, P., Duncan, A., Alabi, $T$ and Blummel, M. 2015. Technical innovations for small- $\mathrm{s}$ c a $1 \mathrm{e}$ producers and households to process wet cassava peels into high quality animal feed ingredients a $n \quad d$ aflasafe ${ }^{\mathrm{TM}}$ substrate.http://www.de velopmentbookshelf.com/doi/abs/ 10.3362/2046-1887.2015.005.

Stavric, S. and Kornegay, E. T. 1995. Microbial probiotic for pigs and poultry. In: Biotechnology in animal feeds and animal feeding. Wallace, R. J. and Chesso, A., eds. VCH Verlagsgesellschaft $\mathrm{mbH}$, Weinheim, Germany. Pp. 205-231.

Tewe, O. O. 1992. Detoxification of cassava products and effects of residual toxins on consuming animals. In Machin D, Nyvold S. Roots, tubers, plantains, and bananas in animal feeding. Proceedings of the FAO Expert consultation held in CIAT, Cali, Colombia, 21-25 January, 1991,FAO,Animal Production and Health Paper- 95

Timmerman, H. M., Koning, C. J. M., Mulder, L., Rombouts, F. M. and Beynen, A. C. 2004. Monostrain, multistrain and multispecies probiotics. A comparison of functionality and efficacy. International Journal of Food Microbiology 96: 219-233.

Tindall, B. J., Grimont, P. A., Garrity, G. M. and Euzeby, J. P. 2005. Nomenclature and taxonomy of the genus Salmonella. International Journal of Systematic and Evolutionary Microbiology 55:521-524.

Received: $11^{\text {th }}$ November, 2017 Accepted: $3^{\text {rd }}$ March, 2018 